\title{
MODEL PENGUATAN KELEMBAGAAN DESA DALAM MENDUKUNG PROGRAM PEMBANGUNAN (Studi Di Desa Jaya Makmur Kecamatan Binongko Kabupaten Wakatobi)
}

La Sadila, Bahtiar, Sulsalman Moita

Program Studi Ilmu Kesejahteraan Sosial, Program Studi Sosiologi, FISIP, Universitas Halu Oleo

Email: Sadila.binongkojm@gmail.com

\begin{abstract}
ABSTRAK
Penelitian ini bertujuan untuk Mendeskripsikan upaya penguatan kelembagaan desa dalam mendukung program pembangunan di Desa Jaya Makmur. Dengan rumusan masalah dalam penelitian ini adalah bagaimana model penguatan kelembagaan desa dalam mendukung program pembangunan di Desa Jaya Makmur. Penelitian ini merupakan penelitian kualitatif yang bersifat deskriptif. Informan penelitian ini ada sepuluh (10) orang stakeholder. Metode pengumpulan data dalam penelitian ini adalah studi literatur, wawancara, observasi lapangan, dan pengambilan foto/dokumentasi dengan sumber data dalam penelitian ini adalah menggunakan data primer dan data sekunder. Teknik yang digunakan dalam analisis data adalah reduksi data, penyajian data, dan penarikan kesimpulan. Jika dilihat dari model penguatan kelembagaan desa sudah teraktualisasikan walaupun masih ada lembaga yang belum terorganisir dengan baik, akan tetapi keberhasilan pelaksanaan program pembangunan di Desa Jaya Makmur pada dasarnya ditentukan oleh sejauh mana komitmen dan konsistensi masyarakat desa saling bekerjasama membangun desa. Hal ini bisa kita lihat pada perlombaan desa, kenapa tidak diadakannya perlombaan desa inilah yang seharusnya menjadi pembelajaran kepada elemen desa untuk mengorganisir masyarakat desa.
\end{abstract}

Kata Kunci: Kelembagaan, Desa, Pembangunan, Kesejahteraan.

\section{PENDAHULUAN}

Berdasarkan Undang-Undang Nomor 23 Tahun 2014 tentang Pemerintahan Daerah yang merupakan pengganti Undang-Undang Nomor 32 Tahun 2004, Desa atau yang disebut nama lain yang selanjutnya disebut Desa adalah kesatuan masyarakat hukum yang memiliki batas-batas wilayah yuridis, berwenang untuk mengatur dan mengurus kepentingan masyarakat setempat berdasarkan asal usul dan adat istiadat setempat yang diakui dan/atau dibentuk dalam sistem Pemerintah Nasional dan berada di Kabupaten/Kota, sebagaimana dimaksud dalam UndangUndang Dasar Negara Republik Indonesia Tahun 1945. Landasan pemikiran dalam pengaturan mengenai desa adalah keanekaragaman, partisipasi, otonomi 
asli, demokratisasi dan pemberdayaan masyarakat. (RKP-Desa Jaya Makmur 2017)

Pengembangan potensi desa harus disesuaikan dengan permasalahan kehidupan atau kebutuhan masyarakat agar hasilnya benar-benar bisa dirasakan untuk meningkatkan kesejahteraan secara luas sesuai tujuan yang telah disepakati bersama. Seperti yang tercantum didalam Nawa Cita Presiden Repulik Indonesia (RI) Kabinet Kerja Joko Widodo dan Jusuf Kalla 2014-2019 menerapkan paradigma pembangunan yang salah satunya "Membangun Indonesia dari pinggiran dengan memperkuat daerah-daerah tertinggal dan desa dalam rangka negara kesatuan" yang berarti membangun daerah-daerah tertinggal dan kawasankawasan perdesaan.

Desa Jaya Makmur yang letaknya berada di Kecamatan Binongko yang begitu strategis untuk menjalankan aktivitas beragam program pembangunan. Disamping wilayahnya memiliki panorama pantai yang indah dan terbentang pasir putih di perairan pesisir pantai begitu elok di pandang. Bagian daratan pegunungannya pun memancarkan keindahan yang berbeda, masyarakatnya pun masih kental dengan sikap kekeluargaan. Hal tersebut merupakan peluang bagi masyarakat Desa Jaya Makmur untuk meningkatkan kelembagaannya dalam merencanakan dan melaksanakan dalam mendukung program pembangunan.

Sebagai wilayah pedesaan tentu saja Desa Jaya Makmur merupakan salah satu dari sekian desa yang ada di Pulau Binongko yang tersentuh oleh programprogram pemerintah. Sehingga sangat memungkinkan menyiapkan kelembagaan desa untuk siap dalam mensukseskan program pembangunan di desa dan semaksimal mungkin meningkatkan kesejahteraan masyarakat desa.

Akan tetapi yang terjadi di Desa Jaya Makmur menunjukkan adanya kondisi pertama, kelembagaan Desa Jaya Makmur masih kurang dalam memberikan pelayanan serta menjawab permasalahan warga (keperluan masyarakat). Kedua kelembagaan Desa Jaya Makmur juga terdapat sekat yang mengakibatkan terhambatnya program pembangunan. Ketidakberdayaan masyarakat Desa Jaya Makmur dapat di lihat dalam proses menyelesaikan broblem sosial, politik, dan 
ekonominya sendiri olehnya itu menyebabkan rancunya struktur kelembagaan serta mandulnya fungsi kelembagaan yang ada di desa.

Kemerdekaan politik nampaknya belum banyak mengubah strategi pembangunan pedesaan yang dikembangkan oleh pemerintah. Jiwa etis politik tetap mewarnai strategi pembangunan pedesaan dalam kaitannya dengan siapa yang mengambil inisiatif dalam proses pembangunan, siapa yang merencanakan program-program pembangunan, dan siapa yang melaksanakan program-program itu. Dari segi ketiga aspek proses pembangunan pedesaan tersebut negara dan aparatnya tetap merupakan unsur yang dominan. Inisiatif pembangunan pedesaan tetap ada pada tangan negara dan aparatnya. Hampir semua departemen mempunyai program pembangunan pedesaan. Kepala desa dan aparatnya masih tetap menjadi entre point yang utama bagi masuknya semua program pembangunan. (Yoserizal 2016: 5-6).

Untuk dapat menjalankan prioritas program pembangunan dan menyentuh permasalahan masyarakat di Desa Jaya Makmur bisa dilihat dari model penguatan kelembagaan di desa. Karna memang tujuan dari kelembagaan desa adalah Untuk memecahkan masalah dan menjalankan prioritas program pembangunan agar dapat terealisasikan dengan baik dalam kemajuan masyarakat di desa, maka perlu adanya peran atau model penguatan kelembagaan desa dalam mendukung program pembangunan seperti Lembaga Pemerintah Desa, Badan Permusyawaratan Desa (BPD), Lembaga Pemberdayaan Masyarakat Desa (LPMD), Pembinaan Kesejahteraan Keluarga (PKK), Lembaga Adat, dan Lembaga Karang Taruna Desa Jaya Makmur.

Komitmen untuk menjalankan prioritas program pembangunan yang diperuntukan untuk menentukan bidang apa saja masyarakat Desa Jaya Makmur menanggulangi permasalahannya, pemerintah Desa Jaya Makmur menyusun Rencana Kerja Pemerintah Desa (RKP Desa) ini mutlak diperlukan agar RKP Desa benar-benar mendorong terwujudnya visi misi daerah secara menyeluruh terutama upaya meningkatkan keberpihakan pembangunan terhadap kebutuhan hak-hak dasar masyarakat Desa Jaya Makmur, seperti pendidikan, kesehatan, pendapatan, dll. 
Berdasarkan latar belakang diatas penulis tertarik untuk membahas model penguatan kelembagaan desa dalam mendukung program pembangunan, sehingga untuk itulah penulis mengajukan judul "Model Penguatan Kelembagaan Desa Dalam mendukung Program pembangunan (Studi di Desa Jaya Makmur Kecamatan Binongko Kabupaten Wakatobi)”.

\section{METODE}

Pendekatan penelitian yang digunakan adalah deskriptif kualitatif, karena pendekatan ini peneliti memandang lebih relevan untuk dapat menggali dengan lebih mendalam perkembangan model penguatan kelembagaan desa dalam mendukung program pembangunan yang ada di Desa Jaya Makmur Kecamatan Binongko Kabupaten Wakatobi.

Menurut Miles dan Huberman (1992: 15-16) penelitian kualitatif adalah penelitian yang sebagian besar datanya berwujud kata-kata bukan rangkaian angka-angka. Data/informasi tersebut dikumpulkan dalam aneka macam cara (Observasi, Wawancara, intisari dokumen, pita rekaman) dan diproses sebelum siap digunakan (melalui pencatatan, pengetikan, penyuntingan atau alih tulis), tetapi analisis kualitatif tetap menggunakan kata-kata yang biasanya disusun kedalam teks yang diperluas (Qodir, A. 2011: 15).

Metode pengumpulan data dengan pendekatan kualitatf dalam penelitian ini dilakukan melalui (Qodir, A. 2011: 19):

1. Studi literatur dari berbagai buku, jurnal, hasil penlitian (tesis) dan media lainnya tentang topik penelitian yang relevan. Selain itu dilakukan juga studi dokumen/arsip untuk memperoleh data sekunder.

2. Wawancara mendalam terhadap informan yang dipilih melalui purposive sampling. Wawancara dalam peneltian ini dilakukan dengan semi terstruktur dan mendalam.

3. Observasi lapangan, pengamatan yang didasarkan pada topik peneletian dan realitas lapangan yang ditemukan.

4. Pengambilan foto/dokumentasi sesuai sasaran dan kebutuhan penelitian. Tehnik ini untuk melengkapi hasil wawancara dan observasi. 


\section{WELVAART}

\section{JURNAL ILMU KESEJAHTERAAN SOSIAL}

Jurusan Ilmu Kesejahteraan Sosial

\section{HASIL DAN PEMBAHASAN}

\section{Deskriptif Lokasi Penelitian}

Semula kampung Jaya Makmur berasal dari kampung Konowali, Wamantogo dan Wangkawaibo yang hampir punah, yang pemukimannya agak jauh dari pesisir pantai.. Pada tahun 1960-an ketiga kampung tersebut di persatukan menjadi Kampung Baru sehinnga pada tahun 26 Juli 2005 di usulkan oleh Panitia pemekaran dan di ganti namanya dari Kampung Baru menjadi Jaya Makmur.

Desa Jaya Makmur merupakan bagian wilayah administrasi dari Kec. Binongko yang berada di wilayah pesisir. Jarak tempat ibu kota Kecamatan \pm 7 $\mathrm{KM}$, luas wilayah $\pm 6,5 \mathrm{Km} 2$ dan luas wilayah pemukiman $\pm 12 \mathrm{Ha}$. Kondisi wilayah Desa Jaya Makmur sedikit berbukit dan berada dibawah lereng gunung, tempat masyarakat bercocok tanam terutama tanaman perkebunan.

Secara administrasi batas-batas wilayah Desa Jaya Makmur adalah:

1. Sebelah Barat berbatasan dengan Desa Oihu

2. Sebelah Timur berbatasan dengan Laut Banda

3. Sebelah Utara berbatasan dengan Desa Lagongnga

4. Sebelah Selatan berbatasan dengan Kelurahan Wali

Jumlah penduduk Desa Jaya Makmur berdasarkan hasil sensus terakhir tahun 2018 mencapai 769 jiwa dengan persebaran penduduk 1.46 persen, dengan jumlah laki-laki 419 jiwa dan perempuan 350 jiwa. Data menunjukan bahwa masyarakat mengandalkan potensi sumberdaya kelautan yang bergerak di bidang perikanan (nelayan) dan pertanian, selain itu sumber mata pencaharian penduduk adalah sebagai, pedagang, pertukangan, buruh, PNS dan sektor-sektor usaha lain.

Penduduk Desa Jaya Makmur masih cukup kuat memegang adat istiadat. Di samping pemerintah desa sebagai penggerak roda birokrasi pemerintah desa, terdapat Sara' yang berperan penting dalam kehidupan sosial masyarakat desa. Sara'-lah yang mengatur dan menjalankan kegiatan-kegiatan yang bersifat adat atau keagamaan seperti dalam acara pernikahan, aqiqah, gunting rambut, sunatan, kematian, dan sebagainya. Mayoritas penduduk Desa Jaya Makmur berasal dari 
etnis Buton. Bahasa sehari-hari yang digunakan masyarakatnya adalah bahasa Cia-Cia. Sementara itu agama yang dianut oleh penduduknya adalah agama islam. Kebiasaan gotong royong juga masih cukup terpelihara misalnya dalam membangun rumah, pesta adat maupun dalam membersihkan lingkungan desa.

\section{Model Penguatan Kelembagaan Desa Jaya Makmur Dalam Mendukung Program Pembangunan}

Kelembagaan desa merupakan wadah penyaluran aspirasi masyarakat desa guna untuk memperjuangkan dan merumuskan prioritas program pembangunan desa. Karena itu, memperkuat kelembagaan desa merupakan suatu keharusan yang tidak dapat diabaikan oleh pemerintah daerah. Dalam meningkatkan kesejahteraan masyarakat desa melalui program pembangunan maka kelembagaan Desa Jaya Makmur memerlukan kesiapan model penguatan kelembagaan guna untuk mendorong percepatan pembangunan di Desa.

\section{Penguatan Kapasitas Kelembagaan Desa Melalui Pendidikan dan Pelatihan}

Kapasitas merupakan sebuah ukuran dalam meningkatkan kemampuan diri seseorang atau lembaga agar dapat menjalankan fungsinya dengan baik. Dalam peningkatan kapasitas dapat pula diartikan denga perlunya ditingkatkan standar kemampuan atau upaya mengusahakan karna belum memenuhi standar yang telah ditetapkan. Demikian halnya dalam mewujudkan kesejahteraan masyarat desa, banyak tantangan yang dihadapi oleh lembaga desa.

Dengan upaya pelaksanana peningkatan kapasitas melalui pendidikan dan pelatihan yang dilakukan oleh pemerntah kabupaten yang pelaksanaannya diadakan di Kecamatan yang di ikuti oleh tokoh masyarakat sangat memberikan kontribusi yang sangat besar untuk keberhasilan penyelenggaraan tugas dan fungsi dalam kaitannya dengan sumber daya manusia. Ketersediaan sumber daya manusia yang baik secara kualitas maupun kuantitas akan menentukan kinerja kelembagaan yang produktif. Mengingat tujuan dilaksanakannya pelatihan akan menambah pengetahuan dan keterampilan para lembaga desa dalam menjalankan tugas dan fungsinya sebagai ujung tombak roda pembangunan di desa.

Maka dari itu penguatan kapasitas melalui pelatihan dan pendidikan merupakan hal yang sangat penting dalam rangka meningkatkan kemampuan 
sumber daya manusia agar bisa membantu dirinya dan orang lain bahkan bisa membantu kelembagaan untuk mencapai pelayanan yang memuaskan.

Dengan demikian Penguatan kapasitas kelembagaan Desa Jaya Makmur melalui pelatihan dilakukan oleh pemerintah daerah merupakan sebuah upaya pemberdayaan manusia (masyarkat desa) dalam memberikan kesempatan untuk mengembangkan kemandirian dan kesejahteraan masyarakat desa dengan meningkatkan pengetahuan, sikap, keterampilan, perilaku, kemampuan, kesadaran, serta memanfaatkan sumberdaya melalui penetapan kebijakan, program, kegiatan yang sesuai dengan esensi masalah prioritas masalah kebutuhan masyarakat desa tanpa menghapus kearifan lokal yang ada di desa.

Aguste Comte menyatakan bahwa semakin tinggi kemampuan masyarakat menggunakan kemajuan berfikir maka akan semakin maju masyarakat (Robert Louer, 1997) dan kemajuan berfikir itu sangat tergantung kepada tingkat pendidikan, oleh karena itu semakin maju pendidikan akan membawa pengaruh positif bagi kemajuan masa depan (Yoserizal. 2016, 43).

\section{Penguatan Kelembagaan Desa Melalui Dukungan Partisipasi Masyarakat}

Kelebagaan desa memiliki fungsi dan peran yang optimal, maka seharusnya lebih meningkatkan kontribusi dan perannya dalam pengelolaan pembangunan. Pengelolaan pembangunan partisipatif memberikan peluang besar bagi masyarakat termasuk kelembangaan desa dalam pengambilan keputusan dan mendayagunakan keswadayaan guna mengembangkan potensi dan menanggulangi permasalahan yang dihadapi dalam rangka mewujudkan mutu kehidupan masyarakat yang lebih baik secara transformatif.

Secara garis besar perencanaan partisipasi mengandung makna adanya keikutsertaan masyarakat dalam proses perencanaan program pembangunan, mulai dari melakukan analisis masalah mereka, dan memikirkan bagaimana cara mengatasinya.

Aspek-aspek yang harus dilakukan dalam pemberdayaan partisipasi masyarakat desa dalam mendukung program pembangunan menekankan pada pemberian kesemapatan kepada masyarakat untuk turut serta dalam proses pembangunan, pemberian kesempatan itu mulai dari membuat pilihan, 
Jurusan Ilmu Kesejahteraan Sosial Universitas Halu Oleo

merencanakan, akses mengambil keputusan, merencakan, mengawasi, mengevaluasi dan sampai kepada pemanfaatannya. Kesempatan yang diberikan kepada masyarakat haruslah melalui proses pembinaan dan pengarahan agar tujuan tepat sasaran.

Berdasarkan temuan di lapangan menemukan bahwa partisipasi masyarakat Desa Jaya Makmur dalam mendudkung program pembangunan cukup baik, dengan adanya berbgai perhatian dari masyarakat terhadap semua perkembangan yang ada dalam lingkup proses pelaksanaan program pembangunan. tentu saja hal ini sangat mendukung program kelembagaan desa dalam pembangunan di desa.

Pemberian kesempatan serta melibatkan masyarakat agar dapat terlibat dalam pembanguna desa dalam hal ini masyarakat sangat antusias dalam pelaksanaan pembangunan di desa, ini dikarenakan masyarakat mendapatkan honor pekerja.

Dengan dilibatkannya masyarakat dalam pembangunan desa maka terbentuklah partisipasi masyarakat dalam pelaksanaan program pembangunan. pembangunan ifrastruktur di desa misalnya memberikan peluang kepada masyarakat desa untuk berpartisipasi secara langsung dan sekaligus meningkatkan pendapatan masyarakat desa. walaupun masyarakat Desa Jaya Makmur ini mendapatkan intrevensi dari masyarakat yang yang kurang setuju dengan pembangunan yang mereka laksanakan akan tetapi tidak menghalangi masyarakat untuk berpartisipasi dalam pelaksanaan program pembangunan di desa dan jiwa yang seperti inilah yang harus dipupuk agar masyarakat tetap mempertahankan nilai-nilai moral mereka sebagai masyarakat desa serta nilai seperti ini yang perlu diwariskan oleh generasi-generasi desa.

Hal ini mengacu pada Dasar hukum partisipasi masyarakat yakni UU 23 Tahun 2014 Pasal 354. Pada ayat 1 dijelaskan bahwa untuk mendorong partisipasi masyarakat maka pemerintah daerah; a) menyampaikan informasi tentang penyelenggaraan Pemerintah Daerah kepada masyarakat; b) mendorong kelompok dan organisasi masyarakat untuk berperan aktif dalam penyelenggaraan Pemerintah Daerah melalui dukungan pengembangan kapasitas masyarakat; c) mengembangkan kelembagaan dan mekanisme pengambilan keputusan yang 
memungkinkan kelompok dan organisasi kemasyarakatan dapat terlibat secara aktif; dan/atau d) kegiatan lainnya sesuai dengan ketentuan peraturan perundangundangan.

\section{Penguatan Kelembagaan Desa Melalui Dukungan Regulasi dan Kebijakan}

Salah satu kebijakan dari pemerintah untuk pembangunan adalah pembangunan dari sisi wilayah dan tata ruang yang memprioritaskan pembangunannya pada pembangunan wilayah pedesaan. Pembangunan pedesaan menjadi prioritas mengingat arti pentingnya pembangunan pedesaan bagi masyarakat pedesaan. Dengan adanya pembangunan maka akan dapat meningkatkan sarana dan prasarana yang ada di pedesaan. Keberadaan sarana dan prasaran tersebut dapat mendukung kegiatan ekonomi, pendidikan, kesehatan dari masyarakat perdesaan. Pada akhirnya akan dapat meningkatkan kesejahteraan masyarakat. Kebijakan hanya akan menjadi kebijakan atau cita-cita semata kalau tidak dapat dilaksanakan.

Berdasarkan temuan di lapangan bahwa dalam proses perencanaan program pembangunan Desa harus di sesuaikan dengan kebijakan peraturan dearah dalam hal ini Pemerintah Kabupaten karena agar pembangunan Desa bisa sejalan dengan visi misi Pemerintah Kabupaten, namun dalam pengambilan kebijakan Desa Jaya Makmur tidak terlepas dari masukan dari musyawarah desa sehingga apa yang menjadi aspirasi masyarakat desa bisa tersalurkan melalui musyawarah desa. Agar kebijakan desa bisa terorganisir dengan baik maka terlebih dahulu lembaga desa membentuk tim seperti Tim Penyusun Program Pembangunan, Tim Pengelola Keuangan Desa dan Tim pelaksana Kerja agar tujuannya untuk bisa mengelola anggaran sesuai peraturan yang berlaku sehingga apa yang menjadi aspirasi masyarakat bisa disesuaikan dengan anggara yang ada.

Sehingga diharapkan prioritas program pembangunan yang akan dilaksanakan nantinya benar-benar berjalan efektif untuk menanggulangi permasalahan di masyarakat, terutama upaya meningkatkan keberpihakan pembangunan terhadap kebutuhan hak-hak dasar masyarakat, seperti pendidikan, kesehatan, pendapatan, dll. Dengan demikian arah dan kebijakan pembangunan desa secara langsung dapat berperan aktif menanggulangi kemiskinan pada level 


\section{WELVAART}

JURNAL ILMU KESEJAHTERAAN SOSIAL

urusan Ilmu Kesejahteraan Sosial

desa maka Desa Jaya Makmur mengadakan musyawarah dengan masyarakat dan dari hasil musyawarah dengan masyarakat dicantumkan kedalam RKP Desa. Rumusan rencana prioritas kebijakan program pembangunan Desa Jaya Makmur tahun 2018 dapat dilihat pada tabel dibawah ini.

Tabel 1: Rumusan Rencana Priortas Kebijakan Program Pembangunan Desa Jaya Makmur Tahun 2018

\begin{tabular}{|c|c|c|c|}
\hline NO & $\begin{array}{l}\text { BIDANG DAN } \\
\text { KEGIATAN }\end{array}$ & TUJUAN & $\begin{array}{l}\text { LOKAS } \\
\text { I }\end{array}$ \\
\hline 1 & 2 & 3 & 4 \\
\hline $\mathbf{A}$ & \multicolumn{2}{|c|}{ BIDANG PENYELENGGARAN PEMERINTAHAN DESA } & $\begin{array}{l}\text { Kantor } \\
\text { Desa }\end{array}$ \\
\hline 1 & $\begin{array}{l}\text { Penghasilan Tetap Kepala } \\
\text { Desa Dan Perangkat }\end{array}$ & Kantor Desa & $\begin{array}{l}\text { Kantor } \\
\text { Desa }\end{array}$ \\
\hline 2 & $\begin{array}{l}\text { Operasional Kantor Dan } \\
\text { BPD }\end{array}$ & Kantor Desa & $\begin{array}{l}\text { Kantor } \\
\text { BPD }\end{array}$ \\
\hline 3 & Pengadaan Laptop & Kantor Desa & $\begin{array}{l}\text { Kantor } \\
\text { Desa }\end{array}$ \\
\hline 4 & $\begin{array}{l}\text { Pengadaan Baju Seragam } \\
\text { BPD }\end{array}$ & Kantor Desa & $\begin{array}{l}\text { Kantor } \\
\text { BPD }\end{array}$ \\
\hline $\mathbf{B}$ & \multicolumn{2}{|c|}{ BIDANG PEMBANGUNAN DESA } & \\
\hline 1. & $\begin{array}{ll}\text { Pemb. } & \text { Gedung } \\
\text { Perpustakaan } & \\
\end{array}$ & $\begin{array}{l}\text { Untuk menumbuhkan minat baca } \\
\text { masyarakat }\end{array}$ & Desa \\
\hline 2. & Pengadaan alat kesehatan & Kebersihan dan kesehatan Lingkungan & Desa \\
\hline 3. & $\begin{array}{lll}\text { Pengadaan } & \text { Tanah } & \text { Kas } \\
\text { Desa } & & \\
\end{array}$ & $\begin{array}{l}\text { Untuk menunjang menunjang kegiatan } \\
\text { pembangunan Desa }\end{array}$ & Desa \\
\hline 4. & $\begin{array}{ll}\text { Pembuatan } & \text { Gedung } \\
\text { Karang Taruna } & \\
\end{array}$ & Penunjang Kegiatan Pemuda & Desa \\
\hline 5. & Batas Dusun. & Memudahkan mengetahui batas dusun & Desa \\
\hline 6. & Jalan Rabat Beton & $\begin{array}{l}\text { Untuk kelancaran akses pemukiman dan } \\
\text { kegiatan masyarakat. }\end{array}$ & Desa \\
\hline 7. & Pengadaan Akses Internet & Untuk ketersediaaan Jaringan & Desa \\
\hline C. & \multicolumn{2}{|c|}{ BIDANG PEMBINAAN KEMASYARAKATAN } & \\
\hline 1. & 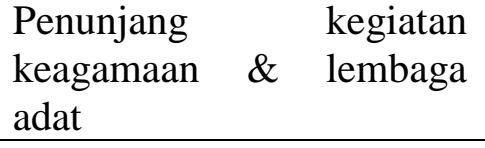 & $\begin{array}{l}\text { Untuk meningkatkan kesejahteraan } \\
\text { perangkat Mesjid dan perangkat adat. }\end{array}$ & Desa \\
\hline 2. & Pembinaan Gerak PKK & Menunjang kegiatan PKK & Desa \\
\hline $\mathbf{D}$ & \multicolumn{2}{|c|}{ BIDANG PEMBERDAYAAN MASYARAKAT } & \\
\hline 1 & $\begin{array}{l}\text { Pelatihan } \\
\text { BHABINKAMTIBMAS }\end{array}$ & $\begin{array}{l}\text { Untuk menguatkan aparat desa dalam } \\
\text { proses perencanaan pembangunan desa. }\end{array}$ & Desa \\
\hline 2. & $\begin{array}{l}\text { Pelatihan penyusunan } \\
\text { Dok. Perencanaan Desa }\end{array}$ & $\begin{array}{l}\text { Untuk menguatkan aparat desa dalam } \\
\text { proses perencanaan pembangunan desa }\end{array}$ & Desa \\
\hline
\end{tabular}

Sumber data : Kantor Desa Jaya Makmur 2018 (di olah) 
Berdasarkan rencana prioritas kebijakan program pembangunan Desa Jaya Makmur yang tersusun dalam RKP Desa Tahun 2018 sepenuhnya didasarkan pada berbagai permasalahan sebagaimana tersebut dalam rumusan masalah di atas. Sehingga diharapkan prioritas program pembangunan yang akan dilaksanakan pada tahun 2018 nantinya benar-benar berjalan efektif untuk menanggulangi permasalahan di masyarakat, terutama upaya meningkatkan keberpihakan pembangunan terhadap kebutuhan hak-hak dasar masyarakat, seperti pendidikan, kesehatan, pendapatan, dan lain-lain. Dengan demikian arah dan kebijakan pembangunan Desa Jaya Makmur secara langsung dapat berperan aktif menanggulangi kemiskinan pada masyarakat.

Kebijakan dan kelembagaan (institusi) sulit dipisahkan, seperti dua sisi sekeping mata uang. Kebijakan yang bagus tetapi dilandasi kelembagaan yang jelek tidak akan membawa proses pembangunan mencapai hasil secara maksimal. Demikian juga sebaliknya, kelembagaan yang bagus tetapi kebijakannya tidak mendukung juga membuat tujuan pembangunan sulit dicapai sesuai harapan. Pengalaman menunjukkan bahwa kegagalan pembangunan seringkali bersumber dari kegagalan negara dan pemerintah dalam membuat dan mengimplementasikan kebijakan yang benar serta mengabaikan pembangunan kelembagaan yang seharusnya menjadi dasar dari seluruh proses pembangunan baik sosial, ekonomi, politik, teknologi maupun pengelolaan sumber daya alam. Ringkasnya kegagalan terjadi karena tata kelola pemerintahan yang buruk (Tony Djogo, Sunaryo, Didik Suharjito dan Martua Sirait: 2003).

Standar dan sasaran kebijakan digunakan untuk menguraikan tujuan-tujuan keputusan kebijakan secara menyeluruh. Dalam menetapkan standar dan sasaran kebijakan harus jelas dan dapat diukur, sebagaimana yang dikemukakan oleh Van Meter dan Van Horn dalam Subarsono (2005: 99) apabila standar dan sasaran kebijakan kabur, maka akan terjadi multiinterpretasi dan mudah menimbulkan konflik. Kinerja kebijakan pada dasarnya merupakan penilaian atas tingkat ketercapaian standar dan sasaran tersebut. 


\section{Penguatan Kelembagaan Desa Melalui Dukungan Anggaran atau Dana}

Dana desa sebagaimana dinyatakan dalam Peraturan Menteri Desa, Pembangunan Daerah Tertinggal, dan Transmigrasi adalah untuk meningkatkan kesejahteraan dan pemerataan pembangunan desa melalui peningkatan pelayanan publik di desa, memajukan perekonomian desa, mengatasi kesenjangan pembangunan antar desa serta memperkuat masyarakat desa sebagai subjek dari pembangunan. Secara spesifik penggunaan dana telah ditetapkan prioritas penggunaannya oleh kementerian terkait setiap tahunnya. Pada tahun 2016, dana desa diprioritaskan untuk pembangunan desa dan pemberdayaan masyarakat desa.

Anggaran yang dipergunakan untuk membiayai program dan kegiatan pembangunan skala desa adalah pendapatan desa yang bersumber dari Pendapatan Asli Desa, Dana Desa dari APBN dan ADD Tahun 2017 (RKP Desa Jaya Makmur 2017). Dalam menjalankan tugas yang diamanahkan oleh masyarkat maka Kelembagaan Desa memerlukan Dana atau Anggaran untuk pembiayaan operasinal.

Berdasrkan temuan di lapangan bahwa Desa Jaya Makmur memiliki kelembagaan desa yang didukung oleh anggaran yang pendapatannya didapat melalui Dana Desa dan juga melalui swadaya masyarakat untuk melaksanakan program pembangunan. tetapi yang akan menjadi majunya desa apabila pendapatan desa itu dipergunakan dengan baik oleh lembaga. Dengan pendapatan yang didapatkan dari anggaran dana desa yang yang diperuntukkan oleh biaya operasional lembaga maka sangat memberikan kemudahan untuk menjalankan tugas dalam hal pelayanan.

Pengelolaan Dana Desa di Jaya Makmur merapakan hal yang tidak terpisahkan dari APBDesa, pengelolaan ini berawal dari perencanaan yang mana akan dibahas di forum Musyawarah Rencana Pembangunan Desa, dimana seluruh lapisan mayarakat diikutsertakan guna mewujudkan pembangunan yang partisipatif dan menampung aspirasi-aspirasi dari masyarakat desa, selanjutnya akan dijadikan acuan untuk menyusun RKPDesa dan APBDesa dan ditetapkan dalam peraturan Desa sebagai pedoman pembangunan desa. 
Setelah Dana Desa diterima pemerintah desa maka Dana Desa tersebut di kelola oleh pemerintah desa beserta perangkat desa dengan melibatkan masyarakat setempat mulai dari perencanaannya yaitu dalam kegiatan musrenbangdes yang mengahadirkan seluruh lapisan masyarakat sampai pada tahap realisasinya yang banyak menyerap tenaga kerja lokal. Berikut adalah tabel penerimaan dana desa tahun 2017-2018.

Tabel 2: Penerimaan Dana Desa di Jaya Makmur Pada Tahun 2017-2018

\begin{tabular}{|c|c|}
\hline Tahun & Total Penerimaan \\
\hline $\mathbf{2 0 1 7}$ & Rp. 1.421 .502 .400 \\
\hline $\mathbf{2 0 1 8}$ & Rp. 1.324 .356 .200 \\
\hline
\end{tabular}

Sumber data: Kantor Desa Jaya Makmur 2018 (di olah)

Berdasarkan tabel di atas dapat di ketahui bahwa total penerimaan DD pada tahn 2017 sebesar Rp. 1.421.502.400. sedangkan pada tahun 2018 menurun menjadi Rp.1.324.356.200. Banyaknya anggaran atau dana yang di dapat oleh desa ternyata membawa kemajuan bagi masyarakat Desa Jaya Makmur kenapa dan apabila Dana yang begitu banyak dipergunakan sesuai Peraturan Pemerintah Republik Indonesia Nomor 8 Tahun 2016 Pasal 1 Ayat 2 maka Desa Jaya Makmur akan lebh maju.

Dana Desa memiliki dampak bagi pembangunan di Desa Jaya Makmur Kecamatan Binongko Kabupaten Wakatobi baik dibidang pembangunan fisik, maupun dibidang pemberdayaan masyarakat. Hal itu dapat dilihat dari infrastruktur seperti jalan desa dan gedung desa di Desa Jaya Makmur yang semakin membaik, sehingga aktivitas masyarakat maupun para lembaga desa berjalan dengan baik. Selain pembangunan fisik, pemberdayaan mesyaakat juga mengalami peningkatan dibanding tahun-tahun sebelumnya. Hal itu dapat dilihat dengan banyaknya kegiatan-kegiatan seperti penyuluhan dan pembinaan terhadap pengurus desa maupun masyarakat untuk masa depan Desa Jaya Makmur yang lebih baik dengan Jaya atas Keakmurannya. 


\section{Penguatan Kelembagaan Desa Melalui Sinergi atau Kolaborasi Antara \\ Lembaga Desa}

Sinergi adalah membangun dan memastikan hubungan kerjasama yang produktif serta kemitraan yang harmonis dengan para kepentingan, untuk menghasilkan karya yang bermanfaat dan berkualitas (Braydenkamma: 2016).

Bentuk sinergi antara pemangku kepentingan di Desa Jaya Makmur dapat kita lihat pada saat ada diadakannya kerja bakti di desa, adanya walimah, dan bahkan pada saat proses perencanaan program pembangunan. demikianlah gambaran sinergi atau kolaborasi pemangku kepentingan yang ada di Desa Jaya Makmur.

Hubungan kerjasama antara lembaga dengan masyarakat di Desa Jaya Makmur masih tumbuh dengan baik, ini kita bisa lihat apabila jika ada kegiatan pembangunan yang akan dilaksanakan. Kalau ada yang perlu disosialisasikan oleh lembaga kepada masyarakat, itu akan cepat diserap oleh masyarakat baik itu berita dari telinga yang satu ketelinga yang lain ataupun melalui informasi atau pemberitahuan dipengeras suara masjid yang diupayakan oleh Panitia masjid bahkan di umumkan secara lisan oleh kepala dusun dengan cara berkeliling kampung untuk melakukan pengumuman kepada masyarakat. Sehingga dengan cara atau upaya seperti itu masyarakat langsung mengetahui. Oleh sebab itu apabila kolaborasi antar lembaga desa bisa berjalan dengan baik maka tidak menutup kemungkinan pembangunan desa akan terus meningkat serta akan menghasilkan pembangunan yang berkualitas.

Apabila dicermati, segala upaya pembangunan dan pemberdayaan masyarakat desa bukan menjadi tanggung jawab pemerintah, melainkan tanggung jawab kita bersama. Untuk itu apabila semua pemangku kepentingan Desa duduk bersama memecahkan masalah yang ada di Desa maka tidak menutup kemungkinan masalah Desa akan mudah terpecahkan.

\section{KESIMPULAN}

Berdasarkan data-data dan wawancara yang ditemukan selama proses penelitian, maka diperoleh kesimpulan bahwa:

1. Penguatan kapasitas kelembagaan Desa Jaya Makmur melalui pendidikan dan pelatihan, bahwa pengurus kelembagaan Desa Jaya Makmur pernah 
mengikuti pelatihan sehingga kesempatan untuk mengembangkan kemandirian dan kesejahteraan masyarakat

2. Penguatan kelembagaan desa melalui dukungan partisipasi masyarakat Desa Jaya Makmur, bahwa pelaksanaan program pembangunan di Desa Jaya Makmur sangat memberikan kebebasan kepada masyarakat untuk selalu berpartisipasi.

3. Penguatan kelembagaan desa melalui dukungan regulasi dan kebijakan di Desa Jaya Makmur, bahwa penetapan prioritas kebijakan pembangunan di Desa Jaya Makmur sepenuhnya termuat dalam dokumen RKP Desa atas dasar musyawarah masyarakat dan seluruh elemen masyarakat.

4. Penguatan kelembagaan desa melalui dukungan anggaran atau dana di Desa Jaya Makmur, bahwa anggaran desa yang digelontorkan oleh pemerintah dapat menarik masyarakat Desa Jaya Makmur dalam menggali potensi desa dalam menyelesaikan masalah yang ada di desa.

5. Penguatan kelembagaan Desa Jaya Makmur melalui sinergi atau kolaborasi, bahwa kerjasama kelembagaan Desa Jaya Makmur belum sepenuhnya berjalan secara maksimal.

Salah satu tantangan pekerja sosial yang paling penting pada saat pertama kali ingin menyebarkan suatu hal yang baru dalam kehidupan sosial adalah membangun lembaga. Karena lembaga akan mewadahi setiap kerangka disiplin ilmu yang berkaitan, disamping itu juga lembaga secara otomatis akan memiliki norma-norma dan etika didalamnya. Lembaga juga bisa menjadi wadah bagi program-program pemberdayaan masyarakat untuk mampu menolong dirinya sendiri dalam mencapai kualiatas hidup yang lebih baik. (Asep Jahidin : 35)

Dalam pelaksanaan penguatan kelembagaan desa dalam mendukung program pembangunan di Desa Jaya Makmur dapat terlaksana dengan baik, maka peneliti menyarankan hal-hal sebagai berikut:

1. Lemabaga-lembaga desa harus meningkatkan penguatan kelembagaan dan sekali-gus memperjelas identitas kelembagaan.

2. Gotong royong yang sudah menjadi ciri khas dari masyarakat Desa Jaya Makmur sebaiknya selalu dipupuk dengan berbagai kegiatan yang dimana 
setiap masyarakat dapat berpatisipasi melalui pelaksanaan pembangunan, tujuannya agar masyarakat dapat lebih menghargai apa yang sudah dibangun bersama.

3. Kelembagaan desa harus selalu mengefektifkan dan mengorganisir kelembagaannya serta harus meningkatkan tingkat pemberdayaan masyarakatnya dalam kegiatan-kegiatan yang produktif.

\section{DAFTAR PUSTAKA}

Adi, Rukminto, Isbandi. 1994. Psikologi, Pekerjaan Sosial dan Ilmu Kesejahteraan sosial (Dasar-Dasar pemikran): PT Raja Grafindo. Jakarta

Adi, Rukminto, Isbandi. 2013. Kesejahteraan Sosial (pekerjaan Sosial, Pembangunan Sosial, dan Kajian Pembangunan): Rajawali Press. Jakarta.

Afni, Wirda. 2017. Analisis pelaksanaan pembangunan desa di desa teluk lecah kecamatan rupat kabupaten bengkalis. Universitas Islam Negeri Sultan Syarif Kasim. Riau.

Daljdjoeni, N dan Suyitno, A. Juli 2004. Pedesaan, Lingkungan dan Pembangunan. Bandung.

Djoko, T. Sirait, M. Suharjito, D. Sunaryo. 2003. Kelembagaan dan Kebijakan Dalam Pengembangan Agroforestri. Bogor Indonesia.

Feriyanto, Nur. 2016. Pemberdayaan Masyarakat Di Desa Sidorejo Kabupaten Purworejo Melalui Penguatan Kelembagaan Berbasis Pengembangan Potensi Lokal. Universitas Islam Indonesia.

Franklin. 2015. Pemberdayaan Masyarakat Perbatasan Desa Nawang Baru Oleh Badan Pemberdayaan Masyarakat Desa (Bpmd) Di Kabupaten Malinau. Samarinda.

Handoko, T., dan Tinov, T. 2016. Penguatan Kelembagaan Desa Dalam Mewujudkan Otonomi Di Desa-Desa Pesisir Studi Di Desa Sokop Kecamatan Rangsang Pesisir Kabupaten Kepulauan Meranti. Riau

Harsanto, TB., Rosyadi, S., Simin, Wahyuningrat. 2017. Penguatan Kelembagaan Kelurahan Pasca Implementasi Uu No. 23 Tahun 2014 Tentang Pemerintahan Daerah. Purwokerto Utara.

Hermansyah. 2015. Peran Kepala Desa Dalam Pelaksanaan Pembangunan Kecamatan Tana Lia Kabupaten Tana Tidung (Studi kasus di Desa Tanah Merah dan Desa Sambungan). Universitas Mulawarman.

Huraerah, Abu. 1429 H/2008 M. Pengorganisasian dan Pengembangan Masyarakat (Model dan Strategi Pembangunan Berbasis Kerakyatan): Humaniora. Bandung.

Jahidin, Asep. Oktober 2016. Epistemologi Ilmu Kesejahteraan Sosial (Perjalanan Dialektika Memahami Anatomi Pekerjaan Sosial Profesional: Samudra Biru (Anggota IKAPI).. Yogyakarta

Kementrian PPN/Bappenas. Tahun. 2017. Dana Desa dan Penanggulangan Kemiskinan. Jakarta.

Moleong, J., Lexy April 1988. Metodologi Penelitian Kualitatif (edisi revisi) : PT Remaja Rosdakarya. Bandung. 


\section{WELVAART}

JURNAL ILMU KESEJAHTERAAN SOSIAL

urusan Ilmu Kesejahteraan Sosial

Murba. 2017. Studi implementasi program pembangunan Infrastruktur di desa erecinnong kecamatan Bontocani kabupaten bone. Universitas Islam Negeri Alauddin Makassar.

Nengsih, Ayu, Mesa. 2015. Respon Peserta Program Keluarga Harapan (Pkh) Terhadap Pelaksanaan Program Keluarga Harapan Di Desa Landuh Kecamatan Rantau Kabupaten Aceh Tamiang. Universitas Sumatra Utara. Medan.

Nugroho, Setyo. 1435 H/2014. Demokrasi dan tata pemerintahan dalam konsep desa dan kelurahan (analisis yuridis pasal 1 (2) UUDNRI 1945 tentang kedaulatan rakyat. Universitas Negeri Syarif Hidayatullah.

Nurasa, Heru. 2016. Analisis Program Pengembangan Kapasitas Kelembagaan Masyarakat Desa Suatu Studi Pada Program Pengembangan Masyarakat Miskin Di Perdesaan. Universitas Padjajaran

Peraturan Pemerintah Republik Indonesia Nomor 8 Tahun 2016 Tentng Peubahan Kedua atas Peraturan Pemerintah Nomor 60 Tahun 2014 Tentang Dana Desa Yang Bersumber Dari Anggaran Pendapatan dan Belanja Negara.

Peribadi. Sabtu 24 September 2016. Revitalisasi Dan Kelembagaan Petani Dan Penguatan Kapasitas Pranata Sosial Perdesaan (Sebuah Diskusi Humaniora Menuju Desa Maju dan Konsel Hebat). FISIP UHO. Kendari.

Prasojo, E. 2003. Perspektif Membangun Partisipasi Publik (People and Society Empowerment). FISIP UI.

Qodir, A. Juli 2011. Analisis kelembagaan dalam upaya pembangunan kesejahteraan masyarakat (studi kasus peranan koperasi jasa keuangan dengan pelaksanaan program pemberdayaan ekonomi masyarakat kelurahan di Kelurahan Kebon Kosong Kecamatan Kemayaron Kotamadya Jakarta Pusat). Depok, Universitas Indonesia.

Rahman, Khairul. Oktober 2016. Pemberdayaan Partisipasi Masyarakat Dalam Pembangunan Desa. Riau.

Rencana Kerja Pemerintah Desa Jaya Makmur (RKP-Desa). Tahun 2017.

Suharto, Edi. 2006. Kebijakan Sosial Sebagai Kebijakan Publik. Bandung: Alfabeta.

Suharto, Edi. 2009. Pekerjaan Sosial di Dunia Industri: Memperkuat Tanggungjawab Sosial perusahaan (Corporate Social Responsibility). Bandung: Alfabeta

Sumpeno, Wahjudin. 2011. Perencanaan Desa Terpadu (edisi Ke- 2): Read Indonesia. Banda Aceh.

Surahman, Fajar. 2010. Model Penguatan Lembaga Kemasyarakatan Dalam Memperkuat Kemandirian Desa. Jurnal Publika. Jurnal Ilmiah Administrasi Negara. Nomor 1 Januari 2010. Universitas Madura.

Suwardianto, S. Juli 2015. Peranan Kepala Desa Dalam Pemberdayaan Masyarakat Di Desa Sidoagung Kecamatan Godean Kabupaten Sleman. Universitas Negeri.

Wulandari, Ayu, Purnami. September 2014. Pemberdayaan masyarakat desa dalam upaya peningkatan kesejahteraan keluarga melalui pelatihan pembuatan sapu gelagah di desa kajongan kecamatan bojongsari kabupaten purbalingga. Universitas Negeri Yogyakarta. 


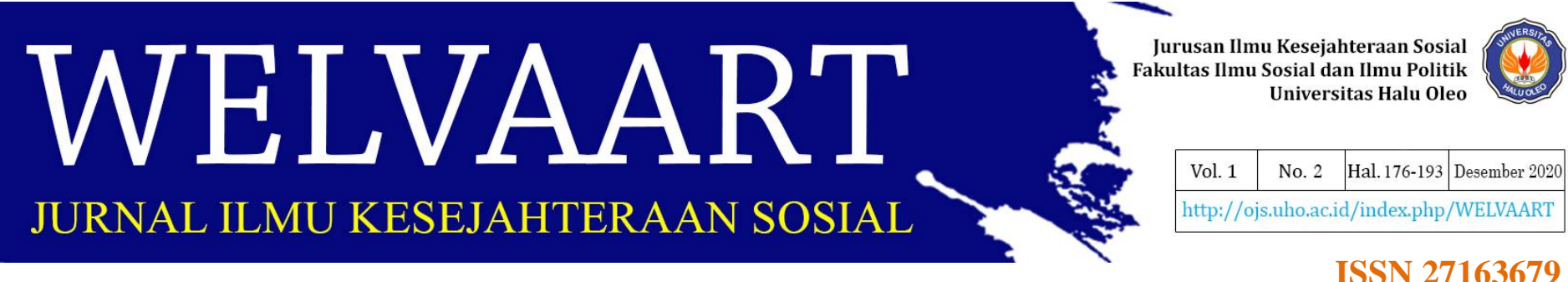

Yoserizal. 2016. Pengembangan Kelembagaan Desa: Alaf Riau. Pekanbaru. http://mudahmurahbagus.wordpress.com/2016/04/23/pengertian-sinergi-adalahmembagun-dan-memastikan-hubungan/

http://www.bangda.kemendagri.go.id/berita/baca_kontent/1060/uu_23_tahun_201 4_menjadi_dasar_hukum_rpp_partisipasi_masyarakat_ 